See discussions, stats, and author profiles for this publication at: https://www.researchgate.net/publication/334731450

\title{
Evaluation of thermal decomposition characteristics and kinetic parameters of melina wood
}

Article in Biofuels · July 2019

DOI: $10.1080 / 17597269.2019 .1646541$

CITATIONS

0

6 authors, including:

Adekunle Akanni Adeleke

University of Ilorin

28 PUBLICATIONS 51 CITATIONS

SEE PROFILE

Olumuyiwa Lasode

University of Ilorin

44 PUBLICATIONS 123 CITATIONS

SEE PROFILE

Some of the authors of this publication are also working on these related projects:

Project High teperature oxidation of Pt-based alloys View project

Composite View project
88

Jamiu Odusote

University of Ilorin

61 PUBLICATIONS 159 CITATIONS

SEE PROFILE

Peter Ikubanni

Landmark University

36 PUBLICATIONS 35 CITATIONS

SEE PROFILE 


\title{
Evaluation of thermal decomposition characteristics and kinetic parameters of melina wood
}

\author{
A. A. Adeleke, J. K. Odusote, O. A. Lasode, P. P. Ikubanni, M. Madhurai \& D. \\ Paswan
}

To cite this article: A. A. Adeleke, J. K. Odusote, O. A. Lasode, P. P. Ikubanni, M. Madhurai \& D. Paswan (2019): Evaluation of thermal decomposition characteristics and kinetic parameters of melina wood, Biofuels, DOI: 10.1080/17597269.2019.1646541

To link to this article: https://doi.org/10.1080/17597269.2019.1646541

曲 Published online: 06 Aug 2019.

Submit your article to this journal 2

View Crossmark data $₫$ 


\title{
Evaluation of thermal decomposition characteristics and kinetic parameters of melina wood
}

\author{
A. A. Adeleke ${ }^{\text {a }}$ D, J. K. Odusote ${ }^{a}$, O. A. Lasode ${ }^{\text {b }}$, P. P. Ikubanni ${ }^{\text {c }}$, M. Madhurai ${ }^{\text {d }}$ and D. Paswan ${ }^{\text {d }}$ \\ ${ }^{a}$ Materials and Metallurgical Engineering Department, University of Ilorin, Ilorin, Nigeria; ${ }^{\mathrm{b}}$ Mechanical Engineering Department, \\ University of Ilorin, Ilorin, Nigeria; ${ }^{\mathrm{C}}$ Mechanical Engineering Department, Landmark University, Omu-Aran, Nigeria; ${ }^{\mathrm{d}}$ Metal Extraction and \\ Recycling Division, CSIR-NML, Jamshedpur, India
}

\begin{abstract}
The evaluation of thermal decomposition characteristics and kinetic parameters of melina wood were investigated. Proximate, ultimate and calorific value analyses of the melina wood were carried out based on standards. Melina wood was subjected to multiple heating rates $\left(5-15^{\circ} \mathrm{C} / \mathrm{min}\right)$ in thermogravimetric experiment. Two prominent isoconversional methods (Flynn-Wall-Ozawa and Starink) were adopted to obtain kinetic parameters from the non-isothermal thermogravimetric analysis curves. The ash, volatile matter and carbon contents of the melina were $2.15,81.42$ and $47.05 \%$, respectively, while the calorific value was $18.72 \mathrm{MJ} / \mathrm{kg}$. The main devolatilization stage of melina ranged from $220^{\circ} \mathrm{C}$ to $350^{\circ} \mathrm{C}$ while $80 \%$ weight loss was obtained below $400^{\circ} \mathrm{C}$. The activation energy varied between approximately 15 and $162 \mathrm{~kJ} / \mathrm{mol}$ as a function of degree of conversion. The pre-exponential factors varied between $1.60 E+2$ and $5.67 E+12 / \mathrm{min}$. The decomposition kinetic mechanism of melina is concluded to be a multi-step reaction.
\end{abstract}

\section{ARTICLE HISTORY}

Received 23 March 2019

Accepted 17 July 2019

\section{KEYWORDS}

Biomass; decomposition; activation energy; isoconversional; preexponential factor

\section{Introduction}

Woody biomass is a renewable energy source that can be an effective feedstock for biofuel production through thermochemical or biochemical conversion [1]. This source of energy is abundantly available in Nigeria. Apart from its availability, it is also a low-cost energy source that can reduce the dependence on fossil fuel thereby reducing quantity of net greenhouse gases emission. One of the exotic woody biomass species in Nigeria is melina. It is a household name in wood and forest industry in Nigeria because of its ability to grow on wide range of soil and climatic conditions [2]. For example, in the south-western part of the country, the plantation of melina was estimated to be about $112 \times 10^{6}$ ha. Melina along with teak plantations are growing larger in Nigeria. The use of melina in the processing company often generate voluminous amount of dust which can be useful for bioenergy and biofuel production. Hence, it is critical to obtain its thermal decomposition behaviour during processing for bioenergy or biofuel production. Balogun et al. [3] carried out the devolatilization kinetic and pyrolytic analyses of Tectona grandis (teak) of Nigeria origin. It was reported that pyrolysis of teak served as a good means of extraction of various biofuel compounds and recommended that further study should be conducted on the devolatilization of other tropical woods. Knowledge of thermal decomposition kinetics of wood polymers is very crucial to further understand the underlying reactions/processes and to provide valuable information for the design and scaling up of pyrolysis reactors [4]. Liu et al. [5] also explained that biomass decomposition is important in the context of thermal conversion that is aimed at production of energy and chemical products. Woody biomass has three major components which include hemicellulose, cellulose, and lignin. Each of these components decompose at different temperature ranges [6]. Kinetic parameters such as activation energy, pre-exponential factors and reaction order play significant role in the thermal decomposition of the three polymers of woody biomass. Thermogravimetric analysis (TGA) or differential thermal analysis (DTA) has been frequently employed in obtaining kinetic parameters and evaluating the thermal behaviour of woody biomass during pyrolysis though with variety of arguments on the absolute use of model-fitting and isoconversional [3, 5, 7, 8]. Markova et al. [9] carried out thermal parameter analyses of beech wood dust and it was reported that, at lower pyrolysis temperature of $260^{\circ} \mathrm{C}$, $90 \%$ of the beech wood sample degraded. It was further reported that thermal degradation of the beech wood is a single-step mechanism. Recent studies have largely adopted isoconversional or model-free techniques due to its ability to handle a multi-step mechanism. Kinetic parameters are majorly evaluated as a function of degree of conversion $(\propto)$. The isoconversional methods were implemented on multiple thermogravimetric experiment which removed all the assumptions of model-fitting methods [3, 7, 8]. Starink [10] and Flynn-Wall-Ozawa [11] methods are the most prominent isoconversional techniques used to obtain decomposition kinetic parameters and both have been adopted for melina in this study. da Silva et al. [12] worked on pyrolysis kinetic evaluation for waste woods (Eucalyptus species) from reforestation. The heating rate adopted was in the range of $5-30{ }^{\circ} \mathrm{C} / \mathrm{min}$ for KissingerAkahira-Sunose, Flynn-Wall-Ozawa and Starink isoconversional methods. The study showed that the thermal decomposition of Eucalyptus species is a multi-step process 
and recommended further study on various biomass to be utilized as source of bioenergy. White et al. [13] stated that there is need to further probe into the different methods of determining pyrolysis kinetic parameters for biomass decomposition. This is to help gain more insight in obtaining more information on the pyrolysis kinetic parameters as there is also very little or no information on the thermal decomposition of melina wood especially of Nigeria origin. Stirred by the rising demand to reduce the violent disposal of woody biomass waste of melina, the present study was conducted in order to investigate the possibility of utilizing melina for bioenergy production by evaluating the decomposition characteristics and its pyrolysis kinetic parameters. Hence, the objective of this study is to generate the thermal decomposition characteristics and pyrolysis kinetic parameters for melina of Nigeria origin using isoconversional techniques. This will help in investigating the ease of its usage for bio-energy and biofuel production purposes.

\section{Materials and methods}

\section{Sample preparation}

The lignocellulosic woody biomass used in this study was melina wood. The lumber was obtained from Benin, Nigeria ( $6^{\circ} 20^{\prime} 17.34^{\prime \prime} \mathrm{N}, 5^{\circ} 37^{\prime} 32.70^{\prime \prime}$ E) and converted into chips and fines below $6.35 \mathrm{~mm}$ using a saw wood cutting machine (Model No: CS33EB). The wood chips and fines were sun-dried for five days ( $6 \mathrm{~h} /$ day). The wood chips were further pulverized into using a Laboratory Mill (Thomas Wiley, Model 4) and screened to $\approx 0.20 \mathrm{~mm}$.

\section{Proximate and ultimate analyses}

Moisture content (MC) was determined according to ASTM E871-82 [14] standard in an oven (Model No: OF-22G, JESO $\mathrm{TECH}$, Korea). A blank glass crucible was weighed in an Electronic Analytical and Precision Balance (Sartorius BSA Series: BSA 224S-CW) and the weight was recorded as $M_{t}$. Approximately $0.5 \mathrm{~g}$ of sun-dried sample was placed inside the glass crucible and weighed. The weight was recorded as $\mathrm{M}_{\mathrm{i}}$. The crucible and the sample were placed in the oven at $105^{\circ} \mathrm{C}$ and removed after $1 \mathrm{~h}$. The final weight $M_{f}$ was taken after the crucible and the sample were allowed to cool inside a desiccator. The moisture content, MC was then calculated using Equation (1);

$$
M C=\frac{M_{f}-M_{t}}{M_{i}-M_{t}} \times 100 \%
$$

where $M_{t}=$ weight of empty glass crucible, $M_{i}=$ weight of glass and sample and $M_{f}$ is the weight of the container and oven-dried sample

The volatile matter (VM) contents of melina wood was determined in accordance with BS EN 15148 [15] standard. A blank alumina crucible with tight fitted lid was sintered at $900^{\circ} \mathrm{C}$ for $7 \mathrm{~min}$, and cooled to room temperature in a desiccator. The weight of the sintered blank alumina crucible and the lid was recorded as $M_{b}$. Biomass sample of $1 \mathrm{~g}$ was weighed into the crucible and the weight of both the covered crucible and the sample was noted as $M_{d}$. The covered crucible and its content were then placed in a muffle furnace (Model No: CBFL518C, USA) that was maintained at $900^{\circ} \mathrm{C}$ for $7 \mathrm{~min}$. After $7 \mathrm{~min}$, the crucible was removed and placed in a desiccator to cool to room temperature. The weight of the crucible and the sample was noted as $M_{e}$ after cooling. The VM was then calculated using the relation in Equation (2);

$$
\operatorname{VM}(\%)=\left(100\left(\frac{M_{d}-M_{e}}{M_{d}-M_{b}}\right)-M C\right) \times \frac{100}{100-M C}
$$

where $M_{b}=$ weight of the empty sintered alumina crucible plus lid (g), $M_{d}=$ weight of sintered crucible plus lid plus sample before heating, $M C=$ moisture content and $M_{e}=$ weight of crucible plus lid plus furnace-dried sample.

The ash content (AC) was carried out in a muffle furnace (Model No: CBFL518C, USA) in accordance with ASTM E1755-01 [16] standard. Biomass sample $(1 \mathrm{~g})$ was placed in a silica crucible and transfer into an oven (Model No: OF$22 \mathrm{G}$, JESO TECH, Korea) for drying at $105^{\circ} \mathrm{C}$ for $1 \mathrm{~h}$, after which it was removed and placed in a desiccator for cooling. The weight was recorded as $M_{\text {od }}$ after cooling. The crucible (containing sample) was then placed in the muffle furnace up to $585^{\circ} \mathrm{C}$ and soaked for $3 \mathrm{~h}$. After which it was removed and observed for possible presence of carbon residue. The presence of some carbon residues in the sample necessitated continuous heating. The crucible and the sample were placed in the furnace for another $1 \mathrm{~h}$ till the weight varies to less than $0.3 \mathrm{mg}$. The final weight of the crucible and sample was recorded as $M_{\text {ash }}$ and ash content was calculated using Equation (3);

$$
A C=\left(\frac{M_{a s h}}{M_{0 d}}\right) \times 100 \%
$$

where $M_{o d}=$ Initial mass of $105^{\circ} \mathrm{C}$ dried sample and crucible $(\mathrm{g}), \mathrm{M}_{\mathrm{ash}}=$ mass of ash and crucible $(\mathrm{g})$.

The fixed carbon (FC) of melina was calculated by difference using Equation (4).

$$
\mathrm{FC}(\%)=100-(\mathrm{MC}+\mathrm{AC}+\mathrm{VM})
$$

The CHN analyses of melina was carried out in a LECO-CHN628 Analyzer (Model No: 622-000-000, SN12357) using ASTM D5373 [17] standard. Oven-dried sample $\left(105^{\circ} \mathrm{C}\right.$ for $\left.1 \mathrm{~h}\right)$ of $0.5 \mathrm{~g}$ was weighed and encapsulated in $a$ thin foil to fit into the Assay Carousal Stackable 30POS that served as holder for the sample in the LECO-CHN628 Analyzer. The sample was transfer into the purge chamber directly above the combustion furnace already at $1300^{\circ} \mathrm{C}$. The combustion process of the sample, reduction of the output gases and display of result took close to $7 \mathrm{~min}$ for each analysis. The result was displayed in percentage mass on computer screen as analyzed by windows-based CHN628Series software connected with the equipment. Sulphur analysis was carried out in a LECO S-144DR Sulphur Determinator (Model No: 606-000-300, SN-477) using ASTM D4239-11 [18] standard. Oven-dried sample $\left(105^{\circ} \mathrm{C}\right.$ for $\left.1 \mathrm{~h}\right)$ of an approximate value of $0.1 \mathrm{~g}$ was weighed into a silica boat crucible. The silica boat crucible was then pushed into the tubular furnace already heated to $1350^{\circ} \mathrm{C}$ where combustion of the sample took place. Sulphur detector then detect the quantity of sulphur present in percentage mass and the result was analyzed using S-144DR software connected with the equipment. Oxygen content was determined by difference using Equation (5)

$$
\mathrm{O}(\%)=100-(\% \mathrm{C}+\% \mathrm{H}+\% \mathrm{~N}+\% \mathrm{~S}+\% \text { Ash })
$$



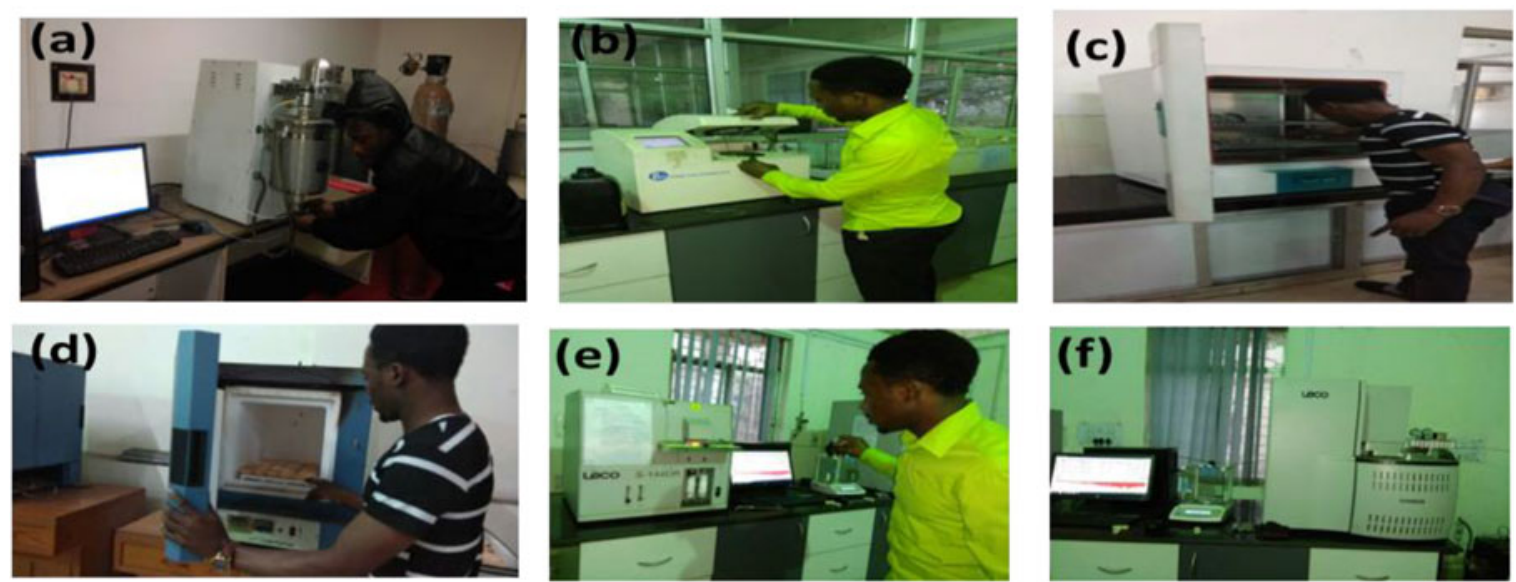

Figure 1. Set up of: (a) a thermogravimetric analyser (Model No: STA7300, $\pm 0.1 \mathrm{~K} / \mathrm{min}$ precision); (b) a Parr 6200 Oxygen Bomb Calorimeter (Model No: A1290DDEE, $\pm 0.001{ }^{\circ} \mathrm{C}$ reading accuracy); (c) an oven (Model No: OF-22G, JESO TECH, Korea) (d) a muffle furnace (Model No: CBFL518C, USA); (e) a LECO S-144DR Sulphur Determinator (Model No: 606-000-300, SN-477 $\leq$ 3\% accuracy); (f) a LECO-CHN628 Analyser (Model No: 622-000-000, $\leq 0.3 \%$ accuracy). Source: Author.

\section{Calorific value}

Calorific value analysis was carried out in a Parr 6200 Oxygen Bomb Calorimeter (Model No: A1290DDEE) shown in Figure 1 using ASTM D5865-04 [19] standard. $0.5 \mathrm{~g}$ of oven-dried sample was completely combusted under a pressurized (3.5 MPa) oxygen atmosphere in the calorimeter. The result was then displayed on the calorimeter. The analysis was carried out in triplicates and the average has been reported.

\section{Thermogravimetric analysis}

The thermal degradation and decomposition behaviour of melina was observed with a thermogravimetric analyser (Model No: STA7300) shown in Figure 1. Sample of $6.5 \mathrm{mg}$ of was loaded into the crucible for analysis in the thermogravimetric analyser. The experiments were carried out in an inert environment obtained by continuous flow of $100 \mathrm{~mL} / \mathrm{min}$ of nitrogen. The samples were heated from $30^{\circ} \mathrm{C}$ to $800^{\circ} \mathrm{C}$ at different heating rates of 5,10 and $15^{\circ} \mathrm{C} / \mathrm{min}[3,12,20]$.

\section{Determination of kinetic parameters}

Model-free technique was used for the determination of kinetic parameters (activation energy $\left(E_{a}\right)$ and pre-exponential factor $(A)$ ) at different degree of conversion $(\propto)$. The technique presumed a single-step reaction (reactant to product) at constant heating rate for the decomposition process. Thus, it eliminates the need for assumption of reaction mechanism.

Equation (6) gave the general form of solid-state rate reaction;

$$
\frac{d \propto}{d t}=K(T) f(\propto)
$$

where the temperature-dependent function is expressed as Arrhenius equation (Equation 7)

$$
K(T)=A e^{-E_{a} / R T}
$$

When $\beta$ (heating rate $)=d T / d t$ is constant and Equations (6) and (7) are combined and integrated, a general singlestep rate equation was obtained (Equation (8))

$$
\int_{0}^{\propto} \frac{d \propto}{f(\propto)}=g(\propto)=\frac{A}{\beta} \int_{T_{0}}^{T} e^{-E_{a}} /{ }_{R T} d T=\frac{A E_{a}}{\beta R} p(x)
$$

where $\propto$ is the degree of conversion, $f(\propto)$ is the reaction model as a function of conversion, $A(/ \mathrm{min})$ is the preexponential factor and $\mathrm{R}$ is the Boltzmann gas constant $(8.314 \mathrm{~J} / \mathrm{mol} / \mathrm{K}) . p(x)$ is the temperature integral and it has no exact analytical solution. Therefore, the solution methods (approximate) proposed by Flynn-Wall-Ozawa (FWO) and Starink were used in this study.

\section{Flynn-Wall-Ozawa (FWO) technique}

This method is a popular model-free technique used for the determination of kinetic parameters. FWO linearized the temperature integral in Equation (8) using Doyle's empirical approximation [21] as shown in Equation (9)

$$
\log p(x) \cong-2.315+0.457 x
$$

Thus, the logarithm of Equation 8 combined with Equation (9) gives FWO expression in Equation (10)

$$
\log \beta=\log \frac{A E_{a}}{g(\propto) R}-2.315-2.315 \frac{E_{a}}{R T}
$$

Therefore, a plot of $\log \beta$ against inverse of corresponding temperature at a conversion yielded isoconversional lines where $E_{a}$ was determine from the slope $\left(-0.457 \frac{E_{a}}{R}\right)$.

\section{Starink's technique}

FWO and Kissinger-Akhira-Sunose (KAS) were two isoconversional techniques that were transformed by Starink. Starink found out that both conformed to the expression in Equation (11)

$$
\ln \left(\frac{\beta}{T^{s}}\right)=C_{s}-\frac{B E_{a}}{R T}
$$

Where $s=0, B=0.457$ for two FWO and $s=0$ and $B=1$ for KAS. These constants $S$ and $B$ were optimized as $S=1.8$ and $B=1.0037$ by Starink. Naik et al. [22] reported that Starink's method was more accurate than FWO and KAS. Therefore, Starink's written as Equation (12) was also used in this study.

$$
\ln \left(\frac{\beta}{T^{1.8}}\right)=C_{s}-1.0037 \frac{E_{a}}{R T}
$$


Table 1. Proximate, ultimate and calorific value of melina and some deciduous woods.

\begin{tabular}{lccc}
\hline Sample & \multicolumn{1}{c}{ Melina } & Teak* & Iroko** \\
\hline & Proximate analysis $(w t . \%$, & db.) \\
MC & $7.52 \pm 0.01$ & 8.60 & \\
VM & $81.42 \pm 1.22$ & 95.50 & 9.40 \\
AC & $2.15 \pm 0.09$ & 0.70 & 70.40 \\
FC & $8.92 \pm 1.31$ & 3.80 & 3.50 \\
& Ultimate analysis (wt.\%, db.) & 26.10 \\
C & $47.09 \pm 0.80$ & 49.60 & \\
H & $6.65 \pm 0.06$ & 6.30 & 43.90 \\
N & $0.38 \pm 0.02$ & 0.40 & 5.30 \\
S & $0.19 \pm 0.01$ & - & 0.40 \\
O & $43.54 \pm 1.61$ & 43.70 & - \\
& Calorific value $(\mathrm{MJ} / \mathrm{kg})$ & & 46.90 \\
& $18.72 \pm 0.43$ & 19.80 & 16.59 \\
\hline
\end{tabular}

*Balogun et al. [3];

**Azeez et al. [21]; db., dry basis.

Thus, $E_{a}$ was obtained from the slope $\left(-1.0037 \frac{E_{a}}{R T}\right)$ of the plot of $\ln \left(\frac{\beta}{T^{1.8}}\right)$ against the inverse of corresponding temperature of a conversion.

\section{Determination of pre-exponential factor $(A)$}

Pre-exponential factor (A) was evaluated according to the modified FWO method adopted as ASTME1641 [23] standard. The $A$ was determined as a function of conversion and based on the assumption that the decomposition obeys first-order kinetics. For a first-order reaction, $n=1$, the value of $A$ was determined using Equation (13);

$$
A=-\beta R / E_{a}(\ln 1-\propto) 10^{a}
$$

where $a$ is the Doyle approximation value and is dependent on the value of $E_{a} / R T$.

\section{Results and discussion}

\section{Characterization of melina}

The proximate, ultimate and calorific value for melina as compared with previous studies for different tropical deciduous woods are presented in Table 1. The proximate analysis gave significant insight into how biomass is expected to behave during pyrolysis [24]. Volatile matter is the content apart from unbound moisture that will be released during pyrolysis. Melina has a relatively high volatile matter contents falling between values reported for iroko and teak wood $[3,25]$. This implied that there is tendency for high devolatilization which can end up as bio-oil or gas. The $2.15 \%$ ash content of melina is higher than $0.7 \%$ for Teak wood reported by Balogun et al. [3] and lower than 3.5\% for iroko wood reported by Azeez et al. [25]. Teak and iroko woods were recommended for bio-oil and solid fuel production based on the percentage ash present. This implied that the inorganic compounds such silica, alumina, calcium oxides, potassium oxides among others in melina are present in quantity usable as feedstock for bioenergy or solid fuel production. The fixed carbon of melina is lower than $26.1 \%$ obtained for iroko wood but higher than $3.8 \%$ of teak wood. The nitrogen content of melina is however within the same range of $0.4 \%$ as iroko and teak woods that were previously reported and this implied that it can also be deployed for bioenergy or solid fuel applications due to the possibility of low emission of $\mathrm{NO}_{\mathrm{x}}$. The energy content of biomass is largely dependent on its

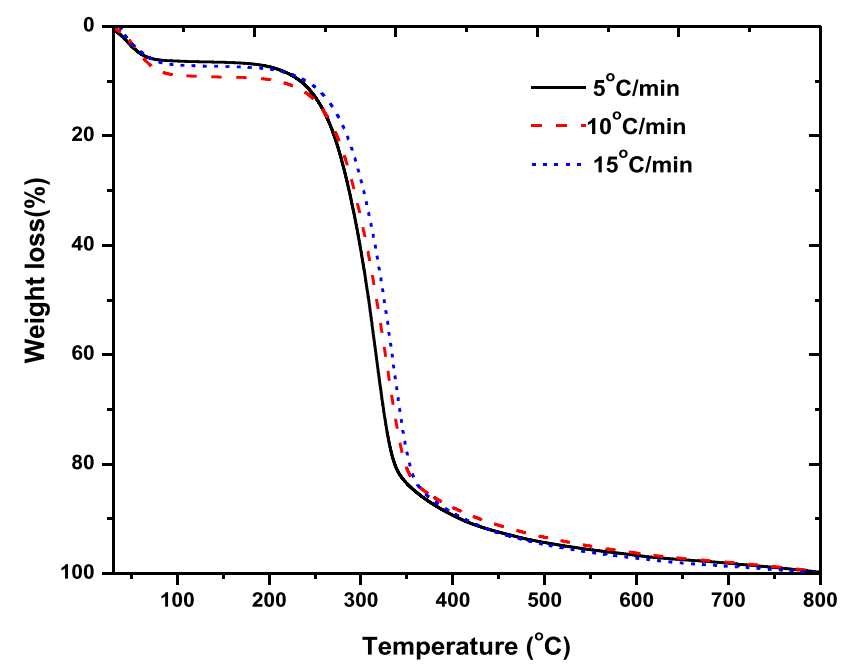

Figure 2. TG curves for melina at different heating rates.

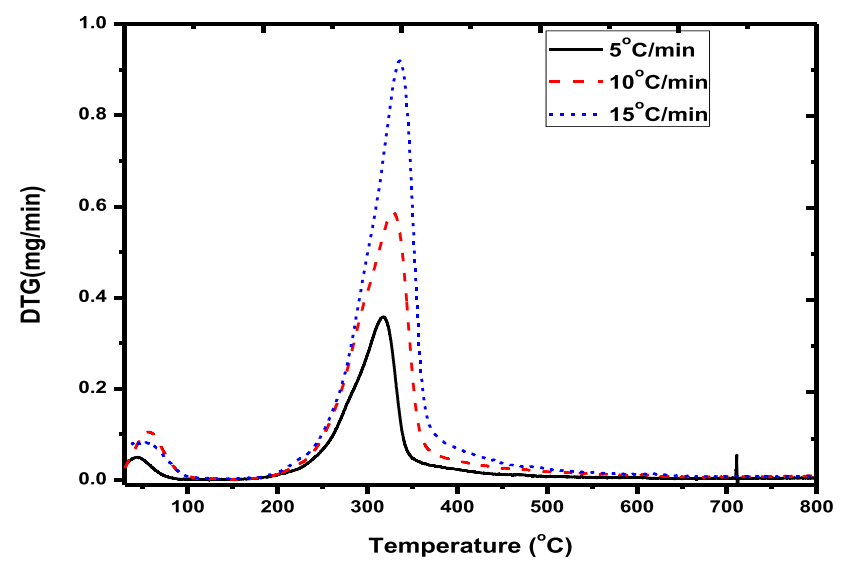

Figure 3. DTG curves for melina at different heating rates.

chemical composition. The carbon content of the present sample is higher than that of iroko but lower than that of teak wood. The trend is reverse for the calorific values of the tropical deciduous woods [3, 24, 25]. It has been observed that low ash and high carbon contents contribute significantly to the calorific value of woody biomass and a similar trend is shown in Table 1. Teak and iroko were recommended for bioenergy application based on their properties such as relatively high-fixed carbon, low ash and high calorific value. The relatively high-fixed carbon and calorific values of melina suggest that it can also be a viable option for bioenergy and solid fuel applications.

\section{Thermal decomposition behaviour of Gmelina arborea}

Figure 2 represents the thermograms for melina at different heating rates and it shows a significant weight loss which was as a result of unbounded moisture evaporation and possibly the degradation of light volatile compounds below $100^{\circ} \mathrm{C}$. This stage was followed by reactive drying phase $\left(100-220^{\circ} \mathrm{C}\right)$ where there was no significant change in weight. The main devolatilization stage of melina ranged from $220^{\circ} \mathrm{C}$ to $350^{\circ} \mathrm{C}$. This stage has been described with wide spectrum of volatile release due to degradation of woody biomass polymers; hemicellulose, cellulose and lignin $[3,26]$. Figure 3 shows the diffractograms (DTG) for melina at different heating rates. The maximum DTG peak temperature for melina ranges from $318^{\circ} \mathrm{C}$ to $336^{\circ} \mathrm{C}$ at 
different heating rate. This was previously attributed to cellulose degradation [3, 26]. Balogun et al. [3] also stated that cellulose decomposed between $320^{\circ} \mathrm{C}$ and $352^{\circ} \mathrm{C}$. The next phase ranged from $340^{\circ} \mathrm{C}$ to $500^{\circ} \mathrm{C}$ and it was typically noted for lignin decomposition. Lignin decomposes over a wider temperature range $\left(195-495^{\circ} \mathrm{C}\right.$ ) according to Lasode et al. [27]. Figure 3 also shows a continuous but minimal weight loss of melina after $500^{\circ} \mathrm{C}$. Balogun et al. [3] explained that this could be as a result of further thermal cracking of some resultant organic compounds or degradation of chemical species that could possibly be formed during the initial devolatilization. The differential thermal analysis (DTA) curve in Figure 4 is a successful tool applied for quantification of heat energy required for phase transition, oxidation, decomposition, adsorption and desorption [7]. Figure 4 reveals that the maximum heat energy consumed was below $400^{\circ} \mathrm{C}$ for the three heating rates. The peak of DTA curves had a shift from $12.26 \mu \mathrm{V}$ to $13.31 \mu \mathrm{V}$ for 5 and $10^{\circ} \mathrm{C} / \mathrm{min}$ heating rates, respectively, while it drops at $15^{\circ} \mathrm{C} / \mathrm{min}$ to $12.66 \mu \mathrm{V}$. It typically depicts that exothermic effects may be lower as heating rate increases from $10^{\circ} \mathrm{C} / \mathrm{min}$. Generally, based on the DTA curves in Figure 4 , it can be concluded that the highest heat energy consumption for the thermal decomposition and degradation lies below $400^{\circ} \mathrm{C}$ at every heating rate, which implied that the process required less external energy consumption as a result of heat been released after this temperature. It thus means that the reaction becomes more exothermic. Table 2 shows the influence of heating rates on devolatilization parameters basically for the region of primary decomposition of melina wood compared with teak wood from the study of [3]. The temperature $\left(T_{\text {onset }}\right)$ at which devolatilization commenced was not affected by variation

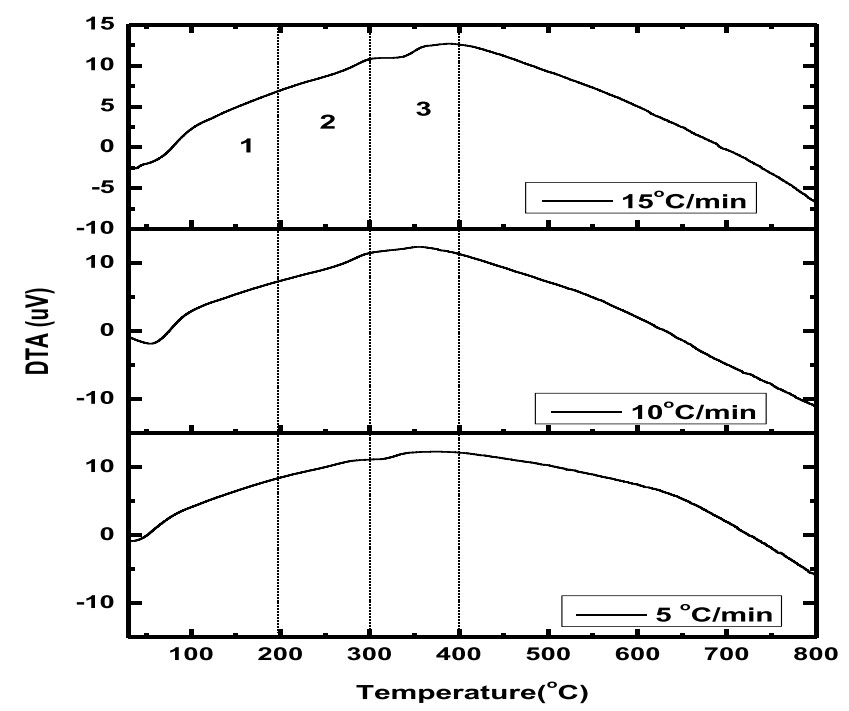

Figure 4. DTA for melina at different heating rates. in heating rate. The temperature at which maximum weight loss occurred ( $T_{\text {peak }}$ ) shifted to a higher one as the heating rate increases. This was similar for the temperature which describes the termination of degradation of cellulose $\left(T_{\text {offset }}\right)$. The temperature at which weight loss of the sample remain relatively unchanged ( $T_{\text {burnout }}$ ) increased as the heating rate increased. The observation of the trend of $\mathrm{T}_{\text {onset }}, \mathrm{T}_{\text {peak }}, \mathrm{T}_{\text {offset }}$, and $\mathrm{T}_{\text {burnout }}$ for melina is similar to that of El-Sayed and Mostafa [7] for bagasse and cotton stock. Table 2 also shows that the maximum cellulose decomposition (DTG peak $)$ increased from $0.3577 \mathrm{mg} / \mathrm{min}$ at $5^{\circ} \mathrm{C} / \mathrm{min}$ to $0.9194 \mathrm{mg} / \mathrm{min}$ at $15^{\circ} \mathrm{C} / \mathrm{min}$. This result is in agreement with the observation of Williams and Ahmad [28] which stated that the maximum weight loss shifted to a higher temperature when oil-shale and lignocellulosic biomass were subjected to pyrolysis in a thermogravimetric analyser. The maximum conversion $\left(\alpha_{\max }\right)$ was higher at $5^{\circ} \mathrm{C} /$ min $(49.96 \%)$ compared to $15^{\circ} \mathrm{C} / \mathrm{min}(48.55 \%)$. It implied that at lower heating rate, the transfer of heat was encouraged by mass diffusion mechanism which facilitated more weight loss. This is similar to the observation of Balogun et al. [3] for thermal decomposition of teak. It was reported that $55 \%$ weight loss was obtained at lower heating rate $(5 \mathrm{~K} / \mathrm{min})$ compared to $48 \%$ at higher heating rate $(35 \mathrm{~K} /$ $\mathrm{min})$. Further degradation of cellulose and lignin continue at $350^{\circ} \mathrm{C}$ to the end of pyrolysis ( $\mathrm{T}_{\text {offset }}$ ) for different heating rates. $\mathrm{Bu}$ et al. [4] attributed this stage to continuous devolatilization with charring. Conclusively, at low heating rates, the transfer of heat is facilitated more and thus, enhances mass diffusion that ultimately leads to a greater weight loss.

\section{Kinetic parameters}

The isoconversional lines in Figures 5 and 6 were derived from the application of FWO (Equation 10) and Starink (Equation 12) derivations, respectively, to the thermogravimetric data (conversion ratio $(\alpha)$ : 0.1-0.95). Figure 7 presents

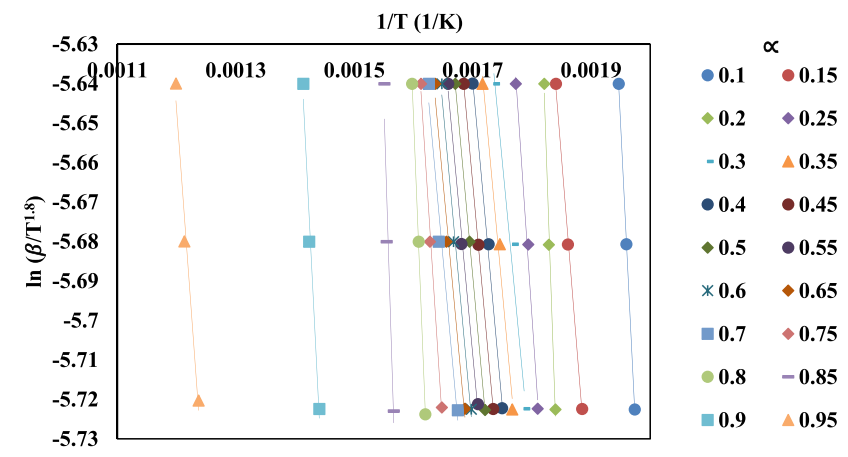

Figure $5 . \ln \left(\beta / T^{1.8}\right)$ against $1 / T$ according to Starink isoconversional method to obtain $\mathrm{Ea}$ at heating rate of 5,10 and $15^{\circ} \mathrm{C} / \mathrm{min}$.

Table 2. Influence of heating rates on devolatilization parameters of sample decomposition.

\begin{tabular}{|c|c|c|c|c|c|c|c|c|}
\hline Sample & $\beta$ & $\mathrm{T}_{\text {onset }}\left({ }^{\circ} \mathrm{C}\right)$ & $\mathrm{T}_{\text {peak }}\left({ }^{\circ} \mathrm{C}\right)$ & $\mathrm{DTG}_{\text {peak }}(\mathrm{mg} / \mathrm{min})$ & $\mathrm{T}_{\text {offset }}\left({ }^{\circ} \mathrm{C}\right)$ & $\alpha_{\max }(\%)$ & $\mathrm{T}_{\text {burnout }}\left({ }^{\circ} \mathrm{C}\right)$ & Ref. \\
\hline \multirow[t]{3}{*}{ Melina } & $5\left({ }^{\circ} \mathrm{C} / \mathrm{min}\right)$ & 191 & 318 & 0.3577 & 444 & 49.96 & 560 & PS \\
\hline & $10\left({ }^{\circ} \mathrm{C} / \mathrm{min}\right)$ & 197 & 326 & 0.4706 & 502 & 49.91 & 607 & PS \\
\hline & $15\left({ }^{\circ} \mathrm{C} / \mathrm{min}\right)$ & 197 & 336 & 0.9194 & 504 & 48.55 & 645 & PS \\
\hline \multirow[t]{4}{*}{ Teak } & $5(\mathrm{~K} / \mathrm{min})$ & 295 & 330 & - & 347 & 55.00 & - & \\
\hline & 15 (K/min) & 311 & 346 & - & 354 & 49.00 & - & 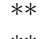 \\
\hline & $20(\mathrm{~K} / \mathrm{min})$ & 322 & 354 & - & 366 & 49.00 & - & $* *$ \\
\hline & 35 (K/min) & 327 & 357 & - & 372 & 48.00 & - & \\
\hline
\end{tabular}

**Balogun et al. [3]; PS, present study. 


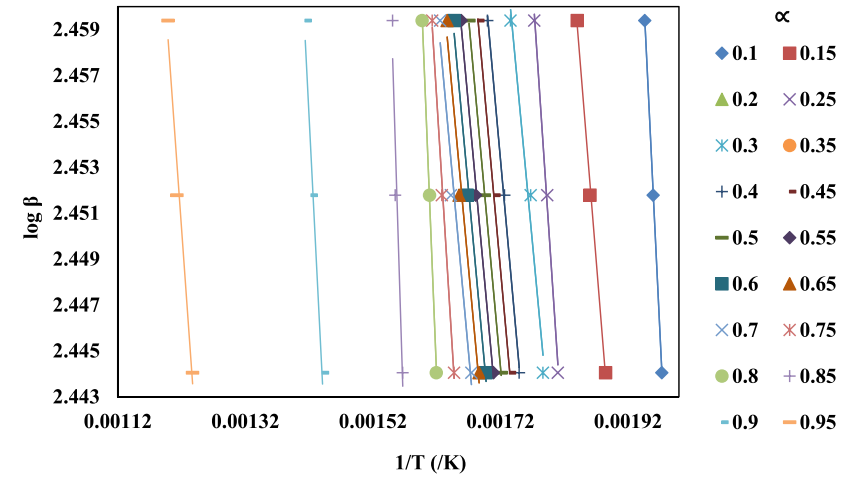

Figure $6 . \log \beta$ against $1 / \mathrm{T}$ according to FWO to obtain $E_{a}$ at heating rate of 5,10 and $15^{\circ} \mathrm{C} / \mathrm{min}$.

Table 3. Pre-exponential and respective determination index $\left(R^{2}\right)$ for different conversion (0.10-0.95) the using FWO method.

\begin{tabular}{lccccc}
\hline FWO & \multicolumn{5}{l}{} \\
\hline $\boldsymbol{\alpha}$ & $\mathrm{A}(/ \mathrm{min})$ & $\mathrm{R}^{2}$ & $\alpha$ & $\mathrm{A}(/ \mathrm{min})$ & $\mathrm{R}^{2}$ \\
\hline $\mathbf{0 . 1 0}$ & $2.13 \mathrm{E}+10$ & 1.0000 & $\mathbf{0 . 5 5}$ & $1.80 \mathrm{E}+06$ & 0.9963 \\
$\mathbf{0 . 1 5}$ & $1.30 \mathrm{E}+07$ & 0.9968 & $\mathbf{0 . 6 0}$ & $3.50 \mathrm{E}+06$ & 0.9885 \\
$\mathbf{0 . 2 0}$ & $1.20 \mathrm{E}+05$ & 0.9854 & $\mathbf{0 . 6 5}$ & $1.90 \mathrm{E}+06$ & 0.9826 \\
$\mathbf{0 . 2 5}$ & $4.70 \mathrm{E}+08$ & 0.9950 & $\mathbf{0 . 7 0}$ & $2.70 \mathrm{E}+06$ & 0.9712 \\
$\mathbf{0 . 3 0}$ & $2.10 \mathrm{E}+06$ & 0.9803 & $\mathbf{0 . 7 5}$ & $2.10 \mathrm{E}+06$ & 0.9591 \\
$\mathbf{0 . 3 5}$ & $1.60 \mathrm{E}+02$ & 0.9929 & $\mathbf{0 . 8 0}$ & $7.80 \mathrm{E}+09$ & 0.9742 \\
$\mathbf{0 . 4 0}$ & $3.10 \mathrm{E}+06$ & 0.9976 & $\mathbf{0 . 8 5}$ & $5.67 \mathrm{E}+12$ & 0.9311 \\
$\mathbf{0 . 4 5}$ & $3.30 \mathrm{E}+06$ & 0.9998 & $\mathbf{0 . 9 0}$ & $1.11 \mathrm{E}+10$ & 0.9758 \\
$\mathbf{0 . 5 0}$ & $5.10 \mathrm{E}+06$ & 0.9993 & $\mathbf{0 . 9 5}$ & $2.30 \mathrm{E}+08$ & 0.9774 \\
\hline
\end{tabular}

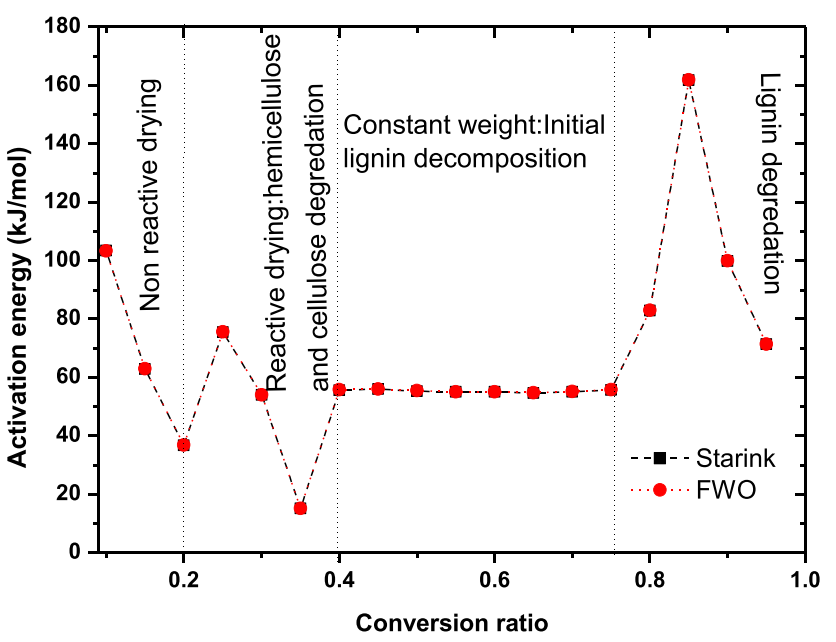

Figure 7. Activation energy against fractional conversion for FWO and Starink methods.

the values of $E_{a}$ calculated from the slopes of Figures 5 and 6 . The activation energy $\left(E_{a}\right)$ obtained for the FWO and Starink methods were close with a minor difference of $<0.1 \%$. The difference could be traced to the iterative procedure of FWO. Starink and FWO methods were stated to have good agreement with a difference of below $0.1 \%$ when used to calculate the activation energy of teak wood by Balogun et al. [3]. The results of the activation energy in the present study also confirm the assertion for melina wood. For the conversion ratio of 0.1 to 0.95 , high determination index $\left(R^{2}\right)$ values were obtained as shown in Table 3. Damartiz et al. [29] and Balogun et al. [3] also reported that the $R^{2}$ were also high for conversion ratios of 0.2 to 0.8 and 0.15 and 0.65 , respectively. This implied that there was a strong correlation for most part of the conversion or decomposition. The activation energy $\left(E_{a}\right)$ dropped from $105 \mathrm{~kJ} / \mathrm{mol}$ to $38 \mathrm{~kJ} / \mathrm{mol}$ for non-reactive drying stage as shown in
Figure 7. The activation energy $\left(E_{a}\right)$ also hovers between 38 and $57 \mathrm{~kJ} / \mathrm{mol}$ for the reactive drying stage which involved initial hemicellulose and cellulose degradation [29]. During the constant weight phase that often indicates the initial lignin decomposition, the $E_{a}$ was relatively constant as shown in Figure 7. However, there was a spike to about $162 \mathrm{~kJ} / \mathrm{mol}$ at conversion rate $(\alpha)$ of 0.85 . This pattern in the fluctuation of activation energy values was also reported by Balogun et al. [3] for teak wood of tropical region. For teak wood, between the conversion ratio of 0.15 and 0.60 , the activation energy hovers between 221 and $260 \mathrm{~kJ} / \mathrm{mol}$ and spikes to about $300 \mathrm{~kJ} / \mathrm{mol}$ at a level of 0.70 [3]. By implication, the activation energy required for the thermal decomposition or pyrolysis of melina is lower than that of teak though followed a similar trend. The variations in activation energy as $\alpha$ increases may be due to the heterogeneous nature of melina polymers in which each possesses a peculiar devolatilization mechanism. The variation in activation energy could also be affected by polymerization of the reacting pyrolysis compounds. The pre-exponential factors shown in Table 3 vary for different conversion ratio. The least pre-exponential factor $(1.60 \mathrm{E}+2 / \mathrm{min})$ was for $\alpha$ of 0.35 while the highest $(5.67 \mathrm{E}+12 / \mathrm{min})$ was for $\alpha$ of 0.85 . The decomposition of lignin in melina requires higher energy and proceeds at lower rate as shown by the pre-exponential factors in Table 3. Generally, as a prelude to further usage of melina for biofuel as solid fuel or source of liquid extracts, the kinetic parameters indicated that the thermal decomposition may require lesser energy input for initiation and completion of several pyrolytic reactions even though it will be a relatively slow process.

\section{Conclusion}

The thermal decomposition characteristics and kinetic parameters evaluation of melina wood have been carried out. The physico-chemical tests showed that melina has a relatively high energy value. The polymers of melina showed different decomposition characteristics though the major devolatilization stage ranged from $220^{\circ} \mathrm{C}$ to $350^{\circ} \mathrm{C}$. Below $400^{\circ} \mathrm{C}$, the decomposition of melina polymers was exothermic and $80 \%$ of the weight was lost. The activation energies varied between 15 and $162 \mathrm{~kJ} / \mathrm{mol}$ while the preexponential factors varied between $1.60 \mathrm{E}+02$ and $5.67 \mathrm{E}+12 / \mathrm{min}$ as a function of conversion ratio.

\section{Nomenclature}

A Pre-exponential factor, $\left(\mathrm{min}^{-1}\right)$

DTG $_{\text {peak }}$ Maximum cellulose decomposition, ( $\mathrm{mg} / \mathrm{min}$ )

DTA Differential thermal analysis

$\frac{d \alpha}{d T} \quad$ Non-isothermal reaction rate

$E_{a} \quad$ Activation energy, $(\mathrm{kJ} / \mathrm{mol})$

$f(\alpha) \quad$ Reaction model

$\mathrm{g}(\alpha) \quad$ Integrated form of conversion dependence

$\mathrm{R}^{2} \quad$ Correlation factor

$\mathrm{T}_{\text {onset }} \quad$ Temperature where devolatization commenced, $\left({ }^{\circ} \mathrm{C}\right)$

$\mathrm{T}_{\text {peak }} \quad$ Temperature for maximum weight loss, $\left({ }^{\circ} \mathrm{C}\right)$

$\mathrm{T}_{\text {offset }} \quad$ Termination of cellulose degradation temperature, $\left({ }^{\circ} \mathrm{C}\right)$

$\mathrm{T}_{\text {burnout }} \quad$ Temperature where constant was maintained, $\left({ }^{\circ} \mathrm{C}\right)$

TGA Thermogravimetric Analysis

$\mathrm{T} \quad$ Temperature $\left({ }^{\circ} \mathrm{C}\right)$

$\alpha_{\max } \quad$ Maximum conversion at $\mathrm{T}_{\text {peak }}(\%)$ 


\section{Greek Symbols}

$\# \alpha \quad$ Fractional conversion

$\beta \quad$ Heating rate $\left({ }^{\circ} \mathrm{C} / \mathrm{min}\right)$

\section{Abbreviations}

ASTM America Standard of Testing and Materials

BS EN British standard

FC Fixed carbon

F-W-O-M Flynn-Wall-Ozawa isoconversion method

MC Moisture content

VM Volatile matter

\section{Acknowledgement}

The authors are also grateful to the Director, CSIR-NML, Jamshedpur, for granting us access to their equipment for the research work and permission to publish the research findings.

\section{Disclosure statement}

No potential conflict of interest was reported by the author(s).

\section{Funding}

This work was supported by The World Academy of Science (TWAS Award No: FR:3240287331), Italy and The Council of Scientific and Industrial Research (CSIR FUND: P-81-1-09), India.

\section{ORCID}

A. A. Adeleke (iD http://orcid.org/0000-0002-0301-7698

D. Paswan (iD http://orcid.org/0000-0001-6183-9828

\section{References}

[1] Demirbas MF, Balat M. Recent advances on the production and utilization trends of bio-fuels: a global perspective. Energy Conver Manage. 2006;47:2371-2381.

[2] Almeida G, Brito JO, Perré P. Technology alterations in energy properties of eucalyptus wood and bark subjected to torrefaction: the potential of mass loss as a synthetic indicator. Biores Technol. 2010;101:9778-9784.

[3] Balogun AO, Lasode OA, McDonald AG. Devolatilisation kinetics and pyrolytic analyses of Tectona grandis (teak). Biores Technol. 2014;156:57-62.

[4] Bu Q, Lei $H$, Qian M, et al. A thermal behavior and kinetics study of the catalytic pyrolysis of lignin. RSC Adv. 2016;6: 100700-100707.

[5] Liu NA, Fan W, Dobashi R, et al. Kinetic modeling of thermal decomposition of natural cellulosic materials in air atmosphere. J Analy Appl Pyroly. 2002;63:303-325.

[6] Mohan D, Pittman CU, Steele PH. Pyrolysis of wood/biomass for bio-oil: a critical review. Energy Fuels. 2006;20:848-889.

[7] El-Sayed SA, Mostafa ME. Kinetic parameters determination of biomass pyrolysis fuels using TGA and DTA techniques. Waste Biomass Valor. 2015;6:401-415.
[8] Okoroigwe E. Combustion analysis and devolatilazation kinetics of gmelina, mango, neem and tropical almond woods under oxidative condition. Int J Renew Energy Res. 2015;5:1024-1033.

[9] Markova I, Ladomersky J, Hroncova E, et al. Thermal analyses of beech wood dust. bioResources. 2018;13:3098-3109.

[10] Starink MJ. A new method for the derivation of activation energies from experiments performed at constant heating rate. Thermochim Acta. 1996;288:97-104.

[11] Flynn JH, Wall LA. A quick, direct method for the determination of activation energy from thermogravimetric data. J Polym Sci B Polym Lett. 1966;4:323-328.

[12] da Silva JCG, Alves JLF, de Araujo Galdino WV, et al. Pyrolysis kinetic evaluation by single-step for waste wood from reforestation. Waste Manage. 2018;72:265-273.

[13] White JE, Catallo WJ, Legendre BL. Biomass pyrolysis kinetics: a comparative critical review with relevant agricultural residue case studies. J Analy Appl Pyroly. 2011;91:1-33.

[14] ASTM E871-82. Standard test method for moisture analysis of particulate wood fuels. West Conshohocken, PA: ASTM International; 2013.

[15] BS EN 15148. Solid biofuels: determination of the content of volatile matter. London, UK: Britsh Standard Institution (BSI); 2009.

[16] ASTM E1755-01. Standard test method for ash in biomass. ASTM fuels. West Conshohocken, PA: ASTM International; 2015.

[17] ASTM D5373. Standard test methods for determination of carbon, hydrogen and nitrogen in analysis samples of coal and carbon in analysis samples of coal and coke. West Conshohocken, PA: ASTM International; 2016.

[18] ASTM D4239-11. Standard test method for sulphur in sample of coal and coke using high temperature tube furnace combustion. West Conshohocken, PA: ASTM International; 2011

[19] ASTM D5865-04. Standard test method for gross calorific value of coal and coke. West Conshohocken, PA: ASTM International; 2004.

[20] Collard FX, Blin J. A review on pyrolysis of biomass constituents: mechanisms and composition of the products obtained from the conversion of cellulose, hemicelluloses and lignin. Renew Sustain Energy Review. 2014;38:594-608.

[21] Doyle CD. Kinetic analysis of thermogravimetric data. J Appl Polym Sci. 1961;5:285-292.

[22] Naik SN, Goud VV, Rout PK, et al. Production of first and second generation biofuels: a comprehensive review. Renew Sustain Energy Rev. 2010;14:578-597.

[23] American Standard of Testing and Material (ASTME1641-07). Standard test method for decomposition kinetics by thermogravimetry. West Conshohocken, PA: ASTM International; 2007.

[24] Jin W, Singh K, Zondlo J. Pyrolysis kinetics of physical components of wood and wood-polymers using isoconversional method. Agricul. 2013;3:12-32.

[25] Azeez A, Meier D, Odermatt J, et al. Fast pyrolysis of African and European lignocellulosic biomasses using Py-GC/MS and fluidized bed reactor. Energy Fuels. 2010;24:2078-2085.

[26] Burhenne L, Messmer J, Aicher T, et al. The effect of the biomass components lignin, cellulose and hemicellulose on TGA and fixed bed pyrolysis. J Analy Appl Pyroly. 2013;101:177-184.

[27] Lasode OA, Balogun OA, McDonald AG. Torrefaction of some Nigerian lignocellulosic resources and decomposition kinetics. J Analy Appl Pyroly. 2014;109:47-55.

[28] Williams PT, Ahmad N. Investigation of oil-shale pyrolysis processing conditions using thermogravimetric analysis. Appl Energy. 2000;66:113-133.

[29] Damartzis TH, Vamvuka D, Sfakiotakis S, et al. Thermal degradation studies and kinetic modeling of cardoon (Cynara cardunculus) pyrolysis using thermogravimetric analysis (TGA). Biores Technol. 2011;102:6230-6238. 